\title{
Fuzzy Electric Generation Modeling from Sea Wave Energy in Gulf of Thailand
}

\author{
S. Phaiboon \\ Department of Electrical Engineer, Faculty of Engineering \\ *Corresponding author
}

\author{
K. Jailearnmee \\ Technology of Information System Management, Faculty of \\ Engineering, Mahidol University, 25/25 Phuttamonthon Sai 4, \\ Salaya \\ Nakornpathom73170, THAILAND
}

\begin{abstract}
This paper presents electrical energy modeling from sea waves in the Gulf of Thailand using fuzzy modeling. We measured the wave height and electric power by using a video camera and multi meters at loads of $300 \mathrm{~W}$. This information is used for modeling to analyze the relationship between the amplitude of the sea wave and the electric power. This model can be used to predict the electrical energy from sea waves as well.
\end{abstract}

Keywords-sea wave; fuzzy modelling; Gulf of Thailand; electric generation

\section{INTRODUCTION}

Currently, renewable energy sources are part of the policy of the Thai government to increase power generation. This is because of oil price increases and the problem of global warming. Therefore, renewable energy sources such as sunlight, wind, and sea waves are needed. Electricity generation from wind turbines and solar cells are frequently used, but there are problems about cost and maintenance. The cost of the electricity generation using wind turbine and solar cells currently average 250 and 160 Baht per watt respectively. Maintenance service costs for turbine and tower problems are more than 15,000 Baht per visit, not including spare parts. Therefore the alternative renewable energy from sea waves is an interesting concept. Power generation from sea waves has been developed since 1970. Many types of wave energy converters (WECs) have been invented, developed and tested in small and large scale experiments. These types are also separated depending on installation: namely, off-shore, nearshore, and on-shore. The off-shore generation has an advantage in the case of maximum power generation. The near-shore generation provides smaller electricity power generation. Although on-shore generation will provide large electricity generation but the large construction will not be environmentally friendly.

Most recently, researchers have invented power generation from sea waves using permanent magnet linear generators. They have direct energy conversion and incompact systems [1-4]. The main components consist of a floating buoy, linear generator and gear box. To obtain the maximum energy from the sea, location of the installation is off shore in deep sea [5]. However the cost of electric transmission and maintenance are increased because of the long distance between the power plant and the land. The research in [6-8] used a fuzzy model to predict electric power from wind energy. It found that the fuzzy model can predict conveniently and accurately. In this paper, we propose electric generation at a near shore location of which the main component consists of a buoy with a $1.2 \mathrm{~m}$ diameter, a $320 \mathrm{~W}$ permanent magnetic generator from a washing machine, and a gear box with ratio of 7:1. Firstly the generator was tested to find the characteristics. Then a buoy and gear box were designed to maximize generation. To implement, the base station was designed and constructed with no footing at the Sirindhorn International Environmental Park in the Gulf of Thailand. The generation system was installed on the base station near shore with 1-3 m depth. The generated electrical energy was recorded with buoyancy movement and sea wave amplitude for modeling of the coupled magnetic-electric-mechanic system. These measurement data is used for analyzing and training the fuzzy model.

\section{ELECTRIC GENERATION FROM SEA WAVES}

The generating section consists of a 350 Watts permanent magnet generator, floating buoyancy and a gear system. The system was installed near-shore in the South of Thailand as shown in Fig. 1.

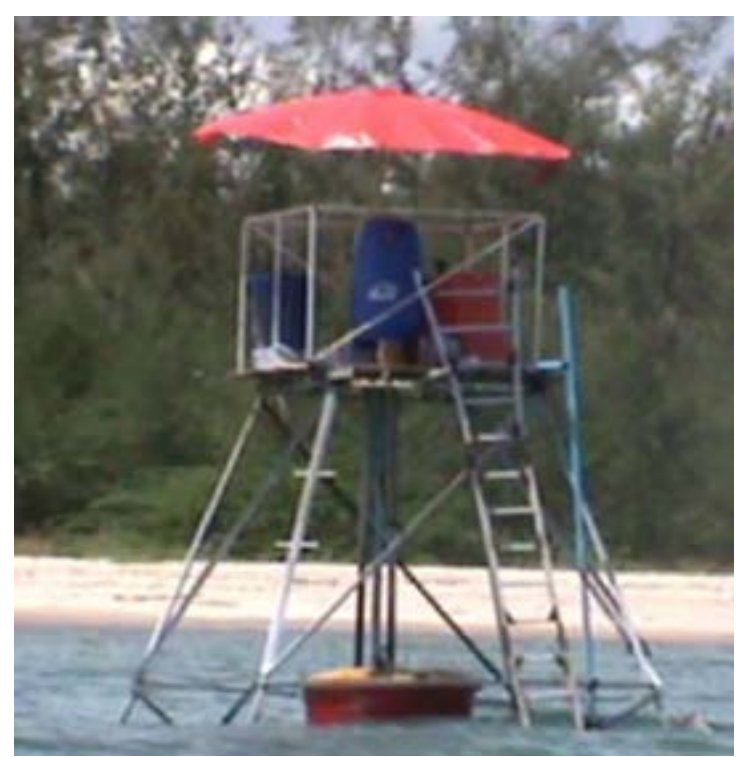

FIGURE I. A PHOTO OF THE NEAR SHORE INSTALLATION HEIGHT. 


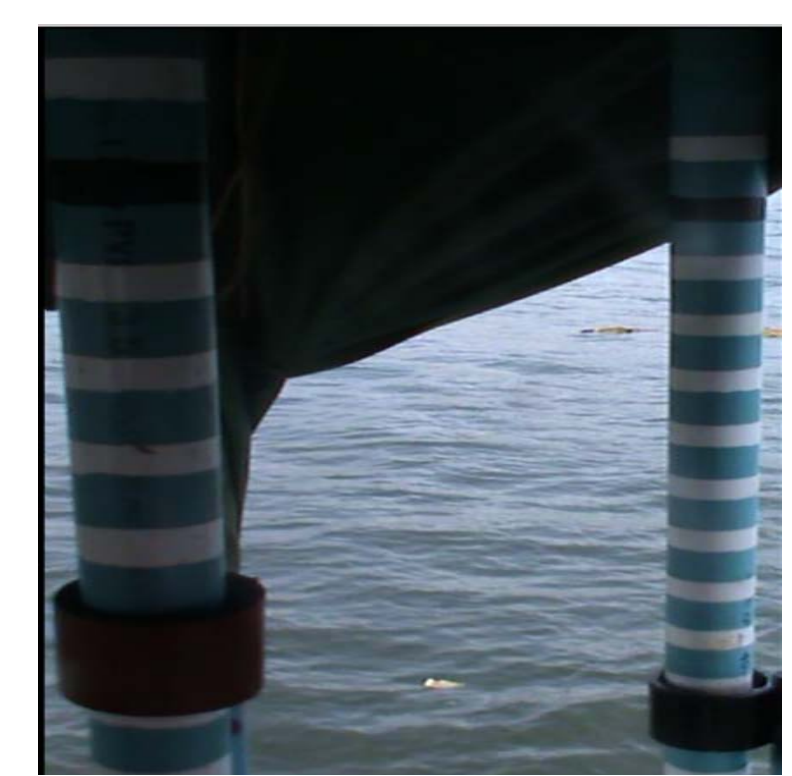

FIGURE II. THE EQUIPMENT FOR MEASURING WAVES (RIGHT) AND FLOATING BUOY HEIGHT (LEFT).

When the wave hits the floating buoyancy, it is raised while the chains drive the gear system and the generator, respectively. Fig. 1 shows a photo of the electric generation in operation.We performed measurement of the wave height and electric power by using a video camera and multi meters at loads of $300 \mathrm{~W}$. This information is used for fuzzy modeling.Measuring the wave height uses PVC pipe with a scale for the wave height as shown in Fig. 2and measuring of electric power uses multi meters. The system was installed at near-shore of the Sirindhorn International Environmental Park, Chaoum, Phetchaburi.

\section{MODELING}

In this study, we performed measurement of the wave height and electric power by using a video camera and multi meters. We found that data at load of $300 \mathrm{~W}$ can be used because it absorbs maximum electric power.

\section{A. Electricenergy Production Analysis}

The selected information of the wave height and electric power are plotted in order to model with fuzzy logic as shown in Fig. 3. The equation for the relationship between wave height and electric power is written as.

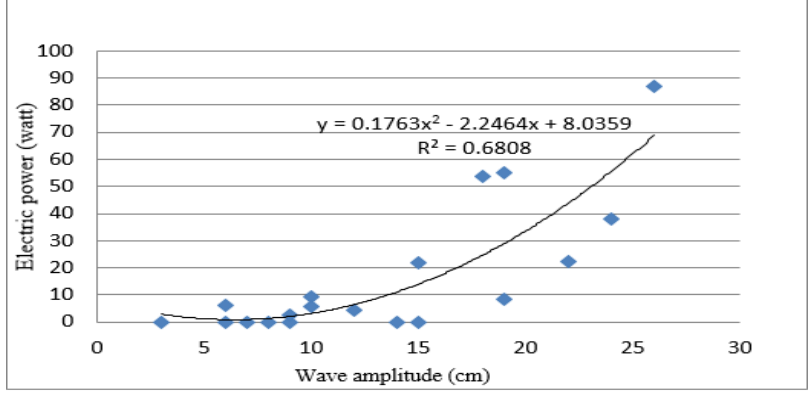

FIGURE III. THE RELATIONSHIP OF WAVE AMPLITUDE AND ELECTRIC POWER IS PRODUCED FROM SEA WAVE.

$$
y=0.176 x^{2}-2.246 x+8.036
$$

When $y$ is electric output power produced, the unit is $\mathrm{W}$ and $\mathrm{x}$ is wave height, the unit is $\mathrm{cm}$.

\section{B. FUZZY MODELING}

From the equation (1), the values are determined for training fuzzy model and testing the fuzzy model.

In this fuzzy modeling, the wave height is input (HW) and electric power is output (Watt). Initially, the number of membership functions is classified into 5 sets namely, nearly zero, small, medium, large and very large as shown in Fig. 4 and Fig. 5.

\section{THE RESULTS OF THE TRAINING}

From the results of the training and testing fuzzy model after 10 rounds, we found that the average of sum of the average percentage error of the training and testing set is minimum value in the ninth rounds.

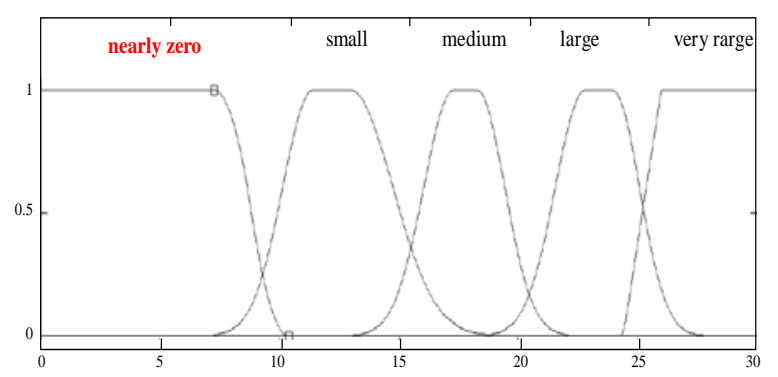

FIGURE IV. FUZZY SET OF INPUT FROM FUZZY MODEL AFTER TRAINING.

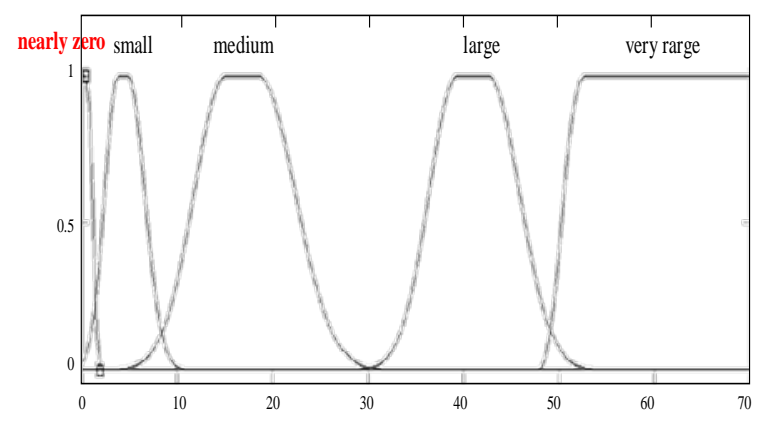

\section{FIGURE V. FUZZY SET OF OUTPUT FROM FUZZY MODEL AFTER TRAINING.}

The meanpercentage of the sum of the average error of the training and testing fuzzy model with a minimum values is about $12.47 \%$.The results from training above, they are summarized as follows.

1) If the amplitude of the sea wave is very small (in the range $0-10 \mathrm{~cm}$, on average $5 \mathrm{~cm}$ ), the electric power is produced very small (in the range $0-2 \mathrm{~W}$, on average $1 \mathrm{~W}$ ).

2) If the amplitude of the sea wave is small (in the range 7 $-17 \mathrm{~cm}$, on average $12 \mathrm{~cm}$ ), the electric power produced is small (in the range $0-10 \mathrm{~W}$, on average 5 Watts).

3) If the amplitude of the sea wave is moderate (in the range $12-23 \mathrm{~cm}$, on average $17.5 \mathrm{~cm}$ ), the electric power 
produced is moderate (in the range $3-30 \mathrm{~W}$, on average 16.5 W).

4) If the amplitude of the sea wave is high (in the range 18 - $28 \mathrm{~cm}$, on average $23 \mathrm{~cm}$ ), the electric power produced is high (in the range $30-55 \mathrm{~W}$, on average $42.5 \mathrm{~W}$ ).

5) If the amplitude of the sea wave is very high (in the range $24 \mathrm{~cm}$. and upper), the electric power produced is very high (in the range $50 \mathrm{~W}$ and upper).

\section{DISCUSSION \&CONCLUSION}

This thematic paper presents results of the electric generation modeling from sea wave energy in the Gulf of Thailand. We installed an electric generator in a near-shore location about 100 meters from the coast. We performed measurement of the wave height and electric power by using a video camera and multi meters at loads of $25 \mathrm{~W}, 40 \mathrm{~W}, 60 \mathrm{~W}$, Table 3 Percentage error of fuzzy model and mathematic model100, $180 \mathrm{~W}$, and $300 \mathrm{~W}$ respectively. This information was used for fuzzy modeling to analyze the relationship between the height of the sea wave and the electric power.

We used a fuzzy model for electric generation modeling. A fuzzy rule consists of five rules, as follows: 1) If the height of the sea wave is very small (in the range $0-10 \mathrm{~cm}$, on average $5 \mathrm{~cm}$ ), the electric power produced is very small (in the range $0-2 \mathrm{~W}$, on average $1 \mathrm{~W}$ ). 2) If the height of the sea wave is small (in the range $7-17 \mathrm{~cm}$, on average $12 \mathrm{~cm}$ ), the electric power produced is small (in the range $0-10 \mathrm{~W}$, on average 5 Watts). 3) If the height of the sea wave is moderate (in the range $12-23 \mathrm{~cm}$, on average $17.5 \mathrm{~cm}$ ), the electric power produced is moderate (in the range $3-30 \mathrm{~W}$, on average $16.5 \mathrm{~W}$ ). 4) If the height of the sea wave is high (in the range $18-28 \mathrm{~cm}$, on average $23 \mathrm{~cm}$ ), the electric power produced is high (in the range $30-55 \mathrm{~W}$, on average $42.5 \mathrm{~W}$ ). 5) If the height of the sea wave is very high (in the range 24 $\mathrm{cm}$. and upper), the electric power produced is very high (in the range $50 \mathrm{~W}$ and upper).

This result shows that if the amplitude of the sea wave is very high, the electric power produced is very high too. Additionally, we found that the maximum output power and the wave amplitude are about $87 \mathrm{~W}$ and $26 \mathrm{~cm}$. respectively. However, if the wave amplitude is more than $26 \mathrm{~cm}$, the mathematic model should be used. The maximum amplitude of sea waves occurs during October to February. If electric power around $200 \mathrm{~W}$ is wanted, the amplitude of the sea wave should be $40 \mathrm{~cm}$.

However, if the amplitude of the sea wave is very high than 3 meters, the generator will be saturated because of the full capacity of the system.

\section{RECOMMENDATION}

In this study, when sea waves near the coast in the Gulf of Thailand havelow height, the electric power produced is less but if we install the generator in deep sea location, far away from the coast more electric power will be produced because the height of sea waves will be higher.
The components of the electric generation system cannot resist corrosion because of salinity of the sea. So, the components should be well protected from this condition for a long life time.

\section{ACKNOWLEDGMENT}

This research project has received research funding from the Electric Authority of Thailand (EGAT) under contract No.53-B104000-051-IO.SS03A300 8088-MU. We thank to Mr.Graham K. Rogers for checking the English.

\section{REFERENCES}

[1] K. Rhinefrank, E. B. Agamloh, and A.VonJouanne, Novel ocean energy permanent magnet linear generator buoy. Renewable Energy, vol. 31, (2006), pp. 1279 - 1298.

[2] O. Danielson, M. Leijon, and E. Sjostedt, Detailed study of the magnetic circuit in a longitudinal flux permanent-magnet synchronous linear generator. IEEE Trans. Magn., vol. 41, no. 9, (2005), pp. 2490 - 2495.

[3] Nikolaos M. Kimoulakis, Antonios G. Kladas, and John A. Tegopoulos, Power Generation Optimization From Sea Waves by Using a Permanent Magnet Linear Generator Drive. IEEE Trans. Magn., vol. 44, no. 6, (2008), pp. 1530 - 1533.

[4] P. Siddorn and R. Eatock Taylor, Diffraction and independent radiation by an array of floating cylinders. Ocean Engineering, vol. 35, (2008), pp. $1289-1303$

[5] I.A. Ivanova, H. Bernhoff, O. Ågren, M. Leijon, Simulated generator for wave energy extraction in deep water. Ocean Engineering, vol. 32, (2005), pp. 1664 - 1678.

[6] Meei-Song Kang., Generation Cost Assessment of an Isolated Power System With A Fuzzy Wind Power Generation Model. IEEE Trans. on Energy Conv., vol. 22, no. 2, (2007), pp. 397 - 404.

[7] Belohlavek, R., and Klir, G. J., Concept and Fuzzy Logic. London, England: The MIT Press, (2011).

[8] Wang, L., A course in fuzzy systems and control, Bernard Goodwin,United States of America, (1997). 